\title{
PENGARUH MODEL PEMBELAJARAN INQUIRY TRAINING TERHADAP HASIL BELAJAR SISWA PADA MATERI KALOR DI KELAS XSEMESTER II SMANEGERI 1 LABUHAN DELI T.P 2014/2015
}

\author{
Mufidah Aziziah Hasibuan dan Alkhafi Maas Siregar \\ Jurusan Fisika FMIPA Universitas Negeri Medan \\ mufidah_aziziah@yahoo.co.id
}

\begin{abstract}
ABSTRAK
Penelitian ini bertujuan untuk mengetahui pengaruh model pembelajaran inquiry training terhadap hasil belajar dan aktivitas siswa. Jenis penelitian ini adalah quasi eksperimen dengan desain two group Pre-test dan Pos-test. Populasi dalam penelitian adalah seluruh siswa kelas $\mathrm{X}$ yang terdiri dari 5 kelas. Pengambilan sampel dilakukan dengan cara cluster random sampling, dimana kelas $\mathrm{X} \mathrm{IPA}^{1}$ sebagai kelas eksperimen dan kelas X IPA ${ }^{2}$ sebagai kelas kontrol. Instrumen yang digunakan tes pilihan berganda dan lembar observasi. Hasil penelitian diperoleh nilai rata-rata pretes kelas eksperimen 38,86 dankelas kontrol 37,57. Nilai ratarata postes kelas eksperimen 76,29 dan kelas kontrol 62,86. Aktivitas siswa di kelas eksperimen mengalami peningkatan dari pertemuan I, II dan III dengan rata-rata nilai seluruhnya adalah $73,33 \%$ dengan kriteria penilaian aktif. Berdasarkan hasil analisis uji $t$, diperoleh ada pengaruh model pembelajaran inquiry training terhadap hasil belajar siswa pada materi kalor di kelas $\mathrm{X}$ semester II SMA Negeri 1 Labuhan Deli T.P 2014/2015.
\end{abstract}

Kata kunci : Model pembelajaran, inquiry training, aktivitas, hasil belajar

\begin{abstract}
The purpose of this research is to know the effect of inquiry training learning model on learning outcomes and student's activity. The type of research is experimental research with desain is two group Pre-test dan Pos-test. The population is all students of class $X$ consist of 5 classes. The sample was selected cluster random sampling, XIPA $A^{1}$ class as experiment class and XIPA ${ }^{2}$ class as control class. The instrument in this research are multiple choices and observation sheet. Result research have the average value of pre-test experiment class is 38,86 and control class is 37,57. The average value of post-test experiment class is 76,29 and control class is 62,86 . The activities of students in the experimental class has increased from the meeting I, II and III with an average total value was $73.33 \%$ as active criteria. Result analysis show, there is an effect of inquiry training learning model on student's learning outcomes in topic heat in class X semester II SMA Negeri 1 Labuhan Deli Academic Year 2014/2015.
\end{abstract}

Keywords: Learning model, inquiry training, activities, learning outcomes

\section{PENDAHULUAN}

Pendidikan memegang peranan

yang sangat penting dalam mempersiapkan manusia yang berkualitas bagi pembangunan Negara.
Keberhasilan membangun disektor pendidikan mempunyai pengaruh yang sangat luas terhadap pembangunan disektor lain. Oleh karena itu, pendidikan hendaknya dikelola dengan 
cara semaksimal mungkin baik secara kualitas maupun kuantitasnya. Menurut Toenas (2012) bahwa kualitas pendidikan tidak dapat terlepas dari kualitas proses pembelajaran yang dilakukan oleh guru. Kualitas pembelajaran dapat dapat dilihat dari aspek proses dan aspek hasil. Masalah yang dihadapi dunia pendidikan kita adalah masalah lemahnya proses pembelajaran. Dalam proses pembelajaran, anak kurang didorong untuk mengembangkan kemampuan berfikir. Proses pembelajaran di dalam kelas diarahkan kepada kemampuan anak untuk menghapal informasi, otak anak dipaksa untuk mengingat dan menimbun berbagai informasi tanpa dituntut untuk memahami informasi yang diingatnya itu untuk menghubungkannya dengan kehidupan sehari-hari(Sanjaya,2013).

Kenyataannya,

kualitas pendidikan Indonesia dianggap oleh banyak kalangan masih rendah. Hal ini bisa dilihat dari beberapa indikator. Pertama, lulusan dari sekolah atau perguruan tinggi yang belum siap memasuki dunia kerja karena minimnya kompetensi yang dimiliki. Kedua, peringkat Human Developmant Indeks Indonesia yang masih rendah. Ketiga, laporan International Educational Achievement bahwa kemampuan membaca siswa SD Indonesia berada diurutan 38 dari 39 dari negara yang di survei. Keempat,mutu akademik antar bangsa melalui Progamme for International Student Assesment 2003 menunjukkan bahwa dari 41 negara yang di survei untuk bidang IPA, Indonesia menempati peringkat ke-38 (Kunandar, 2011).

Fisika merupakan pelajaran yang memberikan pengetahuan tentang alam semesta untuk berlatih berpikir dan bernalar, melalui kemampuan penalaran seseorang yang terus dilatih sehingga semakin berkembang, maka orang tersebut akan bertambah daya pikir dan pengetahuannya. Atas dasar inilah fisika mutlak wajib diajarkan pada setiap siswa. Fenomena tersebut merupakan masalah yang serius dan perlu mendapatkan perhatian penuh dari semua pihak, baik pemerintah, sekolah, masyarakat/orang tua maupun siswa itu sendiri. Rendahnya hasil belajar fisika siswa disebabkan oleh banyak hal antara lain: kurikulum yang padat, materi pada buku pelajaran yang dirasakan terlalu sulit untuk di ikuti, media belajar yang kurang efektif, laboratorium yang tidak memadai, kurang tepatnya penggunaan media pembelajaran yang dipilih oleh guru, kurang optimal dan kurangnya keselarasan siswa itu sendiri, atau sifat konvesional, dimana siswa tidak banyak terlibat dalam proses pembelajaran (Supardi, 2010).

Berdasarkan hasil studi pendahuluan di SMA Negeri 1 Labuhan Deli dengan instrumen observasi angket dan wawancara yang disebarkan ke 35 orang siswa SMA Negeri 1 Labuhan Deli diperoleh, 62,9\% (22 orang siswa) berpendapat fisika adalah pelajaran yang sulit dipahami, dan kurang menarik. 25,7\% (9 orang siswa) berpendapat fisika biasa-biasa saja, dan hanya $11,4 \%$ (4 orang siswa) yang berpendapat fisika menyenangkan dan mudah dimengerti. Data angket juga menunjukkan bahwa sebanyak 31,4\% (11 orang siswa) menyatakan mereka senang mengerjakan soal-soal fisika apabila dilakukan dengan cara berdiskusi atau berkelompok. Serta sebanyak 65,7\% (23 orang siswa) tidak pernah mengemukakan pendapatnya pada saat pelajaran fisika berlangsung, sehingga akibatnya proses belajar mengajar hanya terpaku pada guru saja dan membuat siswa menjadi pasif. Hal ini disebabkan model pembelajaran yang digunakan oleh guru kurang bervariasi.

Selanjutnya penulis melakukan wawancara kepada Ibu Sintauli Lubis mengatakan bahwa hasil belajar siswa belum mencapai Kriteria Ketuntasan 
Minimal (KKM) yang ditetapkan sekolah, yaitu 70. Hal ini terlihat dari hasil ulangan siswa. Selain dari itu, guru juga mengatakan bahwa dalam melaksanakan pembelajaran beliau masih menggunakan model pembelajaran konvensional. Dimana pola mengajar yang digunakan masih menggunakan metode ceramah dan penugasan, dan pembelajaran sering kali dilakukan satu arah (teacher centered). Pada proses pembelajaran, guru jarang melakukan demonstrasi pada materi yang sedang diajarkan. Selain itu, guru juga belum memanfaatkan sarana dan prasarana yang ada di sekolah sehingga siswa jarang melakukan praktikum di dalam laboratorium sekolah. Hal ini mengakibatkan kemampuan siswa seperti melakukan pengamatan, merumuskan hipotesis, menggunakan alat, mengumpulkan data, mengidentifikasi variabel, membuat kesimpulan dan kegiatan yang lain dapat mengembangkan keterampilan proses ilmiah yang ada pada diri siswa tidak tampak.

Menurut (Joyce dkk, 2011) untuk menyingkapi masalah di atas, perlu adanya upaya yang dilakukan oleh guru untuk membuat siswa lebih tertarik mempelajari fisika, mengingat bahwa proses pembelajaran fisika merupakan proses pembelajaran untuk membuktikan sesuatu yang masih teori. Perlu diterapkan model pembelajaran dari fakta menuju teori atau from facts to teories.

Pembenahan dengan menerapkan model pembelajaran inquiry training, permasalahan tersebut diharapkan dapat teratasi. Hal ini didasarkan karena model pembelajaran inquiry training ini diarahkan untuk mengajarkan siswa dalam proses mengkaji dan menjelaskan suatu fenomena khusus. Tujuannya adalah membantu siswa mengembangkan keterampilan intelektual yang diperlukan untuk mengajukan pertanyaan dan menemukan jawabannya berdasarkan rasa ingin tahunya.

Melalui model pembelajaran inquiry training ini siswa diharapkan aktif mengajukan pertanyaan mengapa sesuatu terjadi kemudian mencari dan mengumpulkan serta memproses data secara logis untuk selanjutnya mengembangkan strategi intelektual yang dapat digunakan untuk menemukan jawaban atas pertanyaan mengapa sesuatu terjadi. inquiry training dimulai dengan menyajikan peristiwa yang mengandung teka-teki atau pengetahuan bersifat tentative (tidak pasti) kepada siswa.

\section{METODE PENELITIAN}

Penelitian ini dilaksanakan di SMA Negeri 1 Labuhan Deli yang beralamat di Jalan Serbaguna Pasar IV Helvetia Kec. Labuhan Deli Kabupaten Deli Serdang dimulai pada tanggal 25 April sampai dengan 23 Mei 2015.

Populasi dalam penelitian ini adalah seluruh siswa kelas $\mathrm{X}$ semester II SMA Negeri 1 Labuhan Deli T.P 2014/2015 yang terdiri dari 5 kelas.

Sampel dalam penelitian ini terdiri dari dua kelas yaitu kelas kontrol dan kelas eksperimen yang diambil dengan teknik cluster random sampling. Maka diperoleh kelas X IPA ${ }^{1}$ sebagai kelas eksperimen dengan jumlah siswa 35 orang dan kelas X IPA ${ }^{2}$ sebagai kelas kontrol dengan jumlah siswa 35 orang.

Instrumen yang digunakan adalah tes hasil belajar siswa dan observasi aktivitas siswa. Tes hasil belajar siswa berjumlah dua puluh (20) soal dalam bentuk pilihan berganda. Tes ini diberikan sebanyak 2 kali yaitu pada saat pretes dan postes. Sedangkan observasi yang dimaksud dalam penelitian ini adalah observasi yang dilakukan untuk mengamati keseluruhan aktivitas belajar siswa selama pelaksanaan proses pembelajaran.

Penelitian ini melibatkan dua kelas yang diberi perlakuan yang berbeda. 
Satu kelas dijadikan kelas eksperimen dan satu kelas lainnya dijadikan kelas kontrol. Untuk mengetahui hasil belajar siswa diberikan perlakuan yang berbeda padakedua kelas tersebut. Rancangan penelitian ini sebagai berikut:

Tabel 1. Two Group Pretest - Posttest Design

\begin{tabular}{|c|c|c|c|}
\hline Kelas & Pretes & Perlakuan & Postes \\
\hline Eksperimen & $\mathrm{X}_{1}$ & $\boldsymbol{\mu}_{\mathbf{1}}$ & $\mathrm{X}_{2}$ \\
\hline Kontrol & $\mathrm{X}_{1}$ & $\boldsymbol{\mu}_{\mathbf{2}}$ & $\mathrm{X}_{2}$ \\
\hline
\end{tabular}

Dengan:

$\mathrm{X}_{1}=$ Pemberian pretes

$\mathrm{X}_{1}=$ Pemberian postes

$\mu_{1}=$ Perlakuan dengan model pembelajaran inquiry training

$\mu_{2}=$ Perlakuan dengan model pembelajaran konvensional

Dari hasil pretest yang diperoleh dilakukan uji normalitas dan uji kesamaan rata-rata (uji t) untuk menentukan apakah data berdistribusi normal dan apakah ada perbedaan yang signifikan antara hasil belajar kedua kelas. Selanjutnya kedua kelas diberi perlakuan yang berbeda. Setelah itu kedua kelas diberi postes. Dari hasil postes yang diperoleh dilakukan kembali uji normalitas dan uji kesamaan rata-rata (uji t) untuk menentukan apakah data hasil belajar siswa digolongkan normal dan ada perbedaan yang signifikan antara hasil belajar kedua kelas yang menunjukkan bahwa ada pengaruh atau tidak model pembelajaran inquiry training terhadap hasil belajar siswa.

Aktivitas siswa dilakukan selama proses pembelajaran berlangsung dengan kategori penilaian pada tabel 2 .

Tabel 2. Kategori dan Persentase Nilai.

\begin{tabular}{|l|l|}
\hline Interval & Kriteria \\
\hline $80-100 \%$ & Sangat Aktif \\
\hline $60-79 \%$ & Aktif \\
\hline $40-59 \%$ & Cukup Aktif \\
\hline$<40 \%$ & Kurang Aktif \\
\hline
\end{tabular}

\section{HASIL DAN PEMBAHASAN Hasil Penelitian}

Penelitian diawali dengan memberikan pretes terhadap kedua sampel dengan jumlah soal 20 soal dalam bentuk pilhan berganda yaitu pada kelas eksperimen dan kelas kontrol. Berdasarkan data hasil penelitian diperoleh nilai rata-rata pretes siswa pada kelas eksperimen sebelum diberi perlakuan dengan menggunakan model pembelajaran inquiry trainingsebesar 38,86 dengan standar deviasi 11,57. Sedangkan di kelas kontrol diperoleh nilai rata-rata pretes siswa sebesar 37,57 dengan standar deviasi 12,57.

Kemudian pada kedua kelas diberi perlakuan yang berbeda yaitu pada kelas eksperimen diberi perlakuan menggunakan model pembelajaran inquiry training sedangkan kelas kontrol diberi perlakuan dengan menggunakan model pembelajaran konvensional. Setelah kedua kelas diberikan perlakuan yang berbeda, kedua kelas selanjutnya diberikan postes dengan soal yang sama dengan soal pretes. Hasil yang diperoleh adalah, nilai rata-rata postes kelas eksperimen setelah diterapkan model pembelajaran inquiry trainingsebesar 76,29 dengan standar deviasi 10,47. Sedangkan di kelas kontrol diperoleh nilai rata-rata postes siswa sebesar 62,86 dengan standar deviasi 12,56.

Hasil uji normalitas untuk kedua sampel menunjukkan bahwa kedua kelas berdistribusi normal dimana $L_{\text {hitung }}<\mathrm{L}_{\text {tabel }}$ dan berasal dari populasi yang homogen. Hasil uji hipotesis untuk postes menggunakan uji $\mathrm{t}$ pada taraf signifikan $\alpha=0,05$ diperoleh $t_{\text {hitung }}>t_{\text {tabel }}(4,862>1,997)$ yang berarti bahwa ada beda yang signifikan akibat pengaruh model pembelajaran inquiry training terhadap hasil belajar siswa pada materi kalor.

Aktivitas siswa selama proses pembelajaran juga diamati. Aspek aktivitas yang dinilai antara lain: mendengar - menulis, berfikir kreatif, 
bertanya kepada teman kelompok, bertanya kepada guru, bekerjasama dengan teman kelompok, kegiatan yang tidak relevan dengan KBM, kemampuan memecahkan masalah, mengerjakan LKS/soal, membuat kesimpulan, dan menyajikan hasil karya. Observasi dilakukan selama kegiatan belajar mengajar yang terdiri dari tiga kali pertemuanyang dilakukan oleh duaobserver yaitu rekan sejawat. Dalam penelitian ini, aktivitas siswa setiap pertemuan dalam pembelajaran dapat dilihat pada gambar 1 .

Aktivitas Siswa

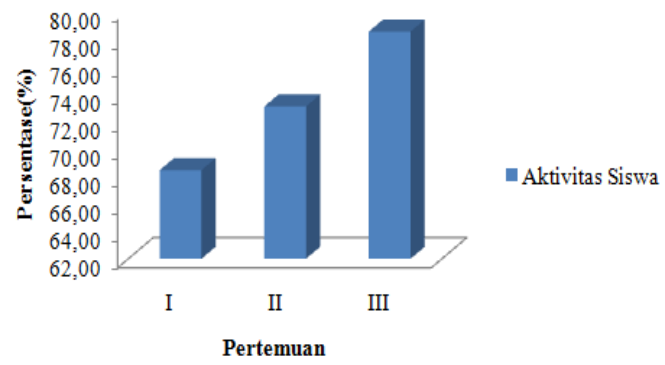

Gambar 1. Aktivitas Siswa Setiap Pertemuan

Berdasarkan Gambar 1 dapat dilihat bahwa hasil pengamatan aktivitas di kelas eksperimen pada pertemuan I 68,44\% tergolong kategori aktif. Pada pertemuan II terjadi peningkatan menjadi $73,06 \%$ pada kategori aktif. Selanjutnya, pada pertemuan III juga terjadi peningkatan aktivitas siswa menjadi $78,50 \%$ yaitu pada kategori aktif. Rata-rata observasi aktivitas yaitu $73,33 \%$ pada kategori aktif. Keaktifan siswa di kelas eksperimen dengan kategori aktif dipengaruhi oleh adanya faktor yang mendukung yaitu penggunaan model pembelajaran. Menurut Bukhori (2012) bahwa pendekatan pembelajaran berbasis inkuiri dapat meningkatkan kompensi guru dalam kegiatan pembelajaran. Hal ini dapat dilihat dari hasil pengamatan terhadap aktivitas pembelajaran di kelas menunjukkan bahwa kompetensi guru tergolong kategori baik dan amat baik.

\section{Pembahasan}

Model pembelajaran inquiry trainingmemberikan pengaruh terhadap hasil belajar pada aspek kognitif karenamodel pembelajaran inquiry training siswa dilibatkan langsung dalam pembelajaran, sehingga siswa menjadi aktif dan kemampuan berpikir siswa dilatih untuk mencari, menyelidiki dan menganalisis pemecahan suatu masalah.

Model pembelajaraninquiry training ini menekankan kepada proses keterlibatan siswa secara penuh untuk dapat menemukan materi yang dipelajari dan menghubungkannya dengan situasi kehidupan nyata sehingga mendorong siswa untuk dapat menerapkannya dalam kehidupan sehari-hari, dalam proses pembelajaran inquiry training siswa tidak hanya berperan sebagai penerima pelajaran melalui penjelasan guru secara verbal, tetapi siswa berperan untuk menemukan sendiri inti dari materi pelajaran. Menurut Mahardika, dkk (2012) bahwa model inkuiri dapat meningkatkan kemampuan representasi verbal, matematis dan hasil belajar siswa. Kemampuan representasi verbal siswa yang menggunakan model inkuiri tergolong tinggi, sedangkan kemampuan representasi verbal siswa yang tidak menggunakan model inkuri tergolong sedang. Kristianingsih, dkk (2010) menyatakan terjadi peningkatan hasil belajar siswa melalui model pembelajaran inkuiri dengan metode pictorial riddle pada pokok bahasan alat-alat optik di SMP.

Selain hasil belajar, dalam penelitian ini juga dilakukan pengamatan aktivitas. Keaktifan siswa di kelas eksperimen dengan kategori aktif dipengaruhi oleh adanya faktor yang mendukung yaitu penggunaan model pembelajaran. Model pembelajaraninquiry training memiliki kelebihan yang salah satunya meningkatkan aktivitas pembelajaran siswa (Sanjaya, 2013). Penggunaan 
model Inquiry Training prinsipnya berpusat pada siswa (student center), sehingga siswa yang lebih banyak berperan dan lebih aktif dalam proses pembelajaran. (Sanjaya, 2013) pembelajaran konvensional sebagai model pembelajaran yang lebih banyak berpusat pada guru dan yang lebih banyak beraktivitas itu adalah seorang guru, sehingga aktivitas siswa cenderung pasif.

Kelebihan yang diberikan dengan menggunakan model pembelajaran inquiry trainingtelah membuat hasil belajar siswa lebih baik dibandingkan dengan pembelajaran konvensional. Tetapi peneliti juga mendapatkan kendala-kendala dalam melakukan penelitian, disamping peneliti baru pertama kalinya melakukan penelitian. Sehingga masih banyak memiliki kekurangankekurangan dalam melaksanakan penelitian. Kendala-kendala dalam penelitian adalah : 1.Adabeberapasiswa yang sulit dalam memahami langkahlangkah pembelajaran dikarenakan kebiasaan belajar siswa yang konvensional.

2. Peneliti kurang mampu mengontrol kelas saat melaksanakan diskusi kelompok sehingga kondisi kelas menjadi kurang kondusif.

Berdasarkan kendala-kendala di atas peneliti dapat meminimalisirnya dengan: 1. Terlebih dahulu peneliti menjelaskan langkah-langkah model pembelajaran inquiry training agar siswa tidak kebingungan untuk mengikuti fase pembelajaran sehingga bisa mengikuti pembelajaran dengan baik, 2. Peneliti hendaknya harus lebih tegas lagi dalam mengontrol kelas saat melaksanakan diskusi kelompok sehingga kelas menjadi lebih kondusif.

\section{KESIMPULAN DAN SARAN Kesimpulan}

Berdasarkan hasil penelitian yang diperoleh maka dapat disimpulkan bahwa hasil belajar siswa dengan menggunakan model pembelajaran inquiry trainingpada materikalor memberikan nilai rata-rata dengan kategori baik. Hasil belajar siswa dengan menggunakan pembelajaran konvensional khususnya pada materi kalor memberikan nilai rata-rata dengan kategori cukup baik. Ada pengaruh yang signifikan akibat model pembelajaran inquiry trainingterhadap hasil belajar kognitif siswa pada materikalor di kelas $\mathrm{X}$ Semester II SMA Negeri 1 Labuhan Deli T.P 2014/2015.Aktivitas siswa yang dikembangkan dari model pembelajaran inquiry trainingdapat meningkatkan keaktifan siswa dalam proses pembelajaran dengan kategori rata-rata aktivitas di setiap pertemuan dinyatakan aktif.

\section{Saran}

Berdasarkan hasil dan kesimpulan dalam penelitian ini, maka peneliti mempunyai beberapa saran, yaitu: (1) Bagi peneliti selanjutnya yang ingin meneliti tentang model pembelajaran inquiry training ini agar peneliti lebih membimbing siswa dengan cara aktif bertanya kepada siswa tentang kendala yang dihadapi, memotivasi, dan mengarahkan agar setiap siswa aktif berdiskusi. (2) Peneliti yang ingin menggunakan model pembelajaran inquiry training hendaknya lebih tegas lagi dalam mengontrol kelas saat melaksanakan diskusi kelompok sehingga kelas menjadi lebih kondusif. (3) Kepada guru yang ingin menggunakan model pembelajaran inquiry training ini supaya mempersiapkan masalahmasalah dalam kehidupan sehari-hari yang lebih menarik dan terkait pada materi pelajaran sehingga siswa akan tertarik mengikuti pelajaran.

\section{DAFTAR PUSTAKA}

Bukhori, M, A., (2012), Pembelajaran Berbasis Inkuiri untuk Optimalisasi Pemahaman Konsep Fisika pada Siswa di SMA Negeri 4 Magelang Jawa Tengah, Berkala Fisika 
Indonesia, Volume 4 Nomor 1 \& 2.

Joyce., B. Weil., M. dan Calhoun., E. 2011. Models of Teaching: ModelModel Pengajaran. Yogyakarta: Pustaka Pelajar.

Kristianingsih, D.D., Sukiswo, S.E., dan Khanafiyah, S., (2010), Peningkatan Hasil Belajar Siswa melalui Model Pembelajaran Inkuiri dengan Metode Pictorial Riddle pada Pokok Bahasan Alat- Alat Optik di SMP, Jurnal Pendidikan Fisika Indonesia (JPFI) 6 : 10-13. ISSN: 16931246

Kunandar. 2011. Guru Profesional. Jakarta: PT. Raja Grafindo Persada.

Mahardika, I.K., Rofiqoh, A., dan Supeno., (2012), Model Inkuiri untuk Meningkatkan Kemampuan Representasi Verbal dan Matematis pada
Pembelajaran Fisika di SMA. Jurnal Pembelajaran Fisika (JPF). Volume 1, Nomor 2. ISSN : 2301-9794.

Sanjaya, W. 2013. Strategi Pembelajaran Berorientasi Standard Proses Pendidikan. Jakarta:Prenada Media Group.

Supardi, dkk. 2010. Pengaruh Media Pembelajaran dan Minat Belajar Terhadap Hasil Belajar Fisika Jurnal Formatif 2(1): 71-81 [online]Tersedia,http://portal.kop ertis3.or.id/bitstream/123456789/ 738/1/Supardi,\%20dkk\%2071-

81.pdf. (Diakses Agustus 2014)

Toenas. 2012. Penerapan Model Inquiry Training Melalui Teknik Peta Konsep dan Teknik Puzzle Ditinjau dari Tingkat Keberagaman Aktivitas Belajar dan Kemampuan Memori, Vol1, No 3 (hal 258-265). Jurnal. Pasca. Uns. Ac. Id 